\title{
Value creation in relationship exchange explication by Ethical Approach: an application in the field of services To Moroccan SMES
}

\author{
Jamila Jouali,' Youssef Jouali, Abdellatif Chakor \\ Faculty of Economic Sciences Morocco University Mohammed V-Souissi, Rabat, Morocco
}

\begin{abstract}
This research developed an integrative model to explain the impact of the ethical dimension and bonding on value relationship in the field of services to morocco SMES on inter organizational context. In this article, the authors provide a thorough conceptualization of value relationship and its possible antecedents, i.e., bond relationship; equity drawing on an empirical base of 240 SMEs questionnaires, Structural equations modeling (SEM) is used to evaluate the simultaneous effects of the predictive variables. Implications for marketers' academicians and managers are discussed, and areas for future research are presented.
\end{abstract}

Key word: Equity, social bond, structural bond, value relationship.

\section{INTRODUCTION:}

Collaborative processes play an important role in the business marketing literature, as close interaction between buyers and sellers is a key to understanding inter-organizational exchanges. The majority of the academic describing buyer-supplier relationship emphasized

Its interactive (Hakansson 1982, Ford \& al. 1986), as long term orientation (Griffith \& al., 2006; Johnston \& al., 2004), source of increased performance, According to (Ropo and Sauer (2003)), the successful partnership is based on shared value. The strength relation can improved operational performance outcomes or facilitate to acquire a competitive advantage for the involved parties (Day, 2000; Krause et al., 2007)

Theoretical bases of these models are different (Dwyer at al.1995); some of them focus on the interactive exchange process (Hakansson 1982) others, the effects of the exchange or the development phases of the buyer-seller relationships (Ford 1980, Wilson 1995). Dyadic collaborating with seller's buyers over time be able to generate value by favoring acquirement information and exchange. Although "value" creation and value sharing, can be regarded as the raison of collaborative sellers and buyers relationships" (Anderson 1995).Research on relational governance exchange, advance that a key mechanism that makes possible such exchange to generate value is the nature of the relationship. Therefore, the development of a relationship whose nature has certain attributes is prerequisite to functional relational exchange. Particularly, such a relationship has high levels of such "relational" attributes as trust, commitment equity and relational bonds (e.g., Morgan \& Hunt 1994). Bendapudi \& Berry (1997) define relationship enhancement from a buyer's perspective as "broadening and deepening the relational bonds with the service provider. Bonds of different kinds are said to develop between cooperating companies due to mutual adjustment between the counterparts. Berry (1995) introduced the concept of relational bonding levels that are categorized as financial, social, and structural. Bonds of different kinds are said to develop between cooperating companies due to mutual adjustment between the counterparts. Berry (1995) introduced the concept of relational bonding levels that are categorized as financial, social, and structural. Gundlach \& Murphy (1993) explored the role of ethics and law in relational exchange. Contract law provides for the negotiation and consummation of formal relationships; however, it can impede relational bonds the ethical behavior of sellers plays a significant role in the formation and the continuance of relations with customers (Lagace et al. 1991;Gundlach \& Murphy, 1993). To understand and judge the value relationship process a number of crucial questions become evident. The objective of this research is to understand how those relational bonds and ethical dimensions can generate value to SMES in context of Business to Business.

\subsection{ReLATIONAL BOND}

\section{THEORETICAL BACKGROUND}

Bonding has been examined as an important dimension of a business relationship linking buyer and seller acting in an interconnected way toward a desired target. Different types of bond cited in marketing theoretical framework. We adopted the classification of (Yet, Arantola (2002)), who can make a distinction between two categories: social and structural bond. Proposed that a relational bond is a key aspect of relationship.. This is because bonding as it applies to relationship marketing refers to the feelings of affection 
and a sense of belonging to the relationship which it indirectly causes a sense of belonging to the organization (Sin et al., 2002).

\subsubsection{SOCIAL BONDS}

Social bonds connect and hold a buyer and seller closely together (Han, 1991), this bond serves to continue in the relationship, and represent the degree of mutual friendship and liking shared by the buyer and seller (Wilson, 1995). (Bagozzi, 1978) notes that social bond can be seen as an instrument that adds value to the dyadic seller -buyer by addressing the needs that the buyer has for a close personal relationship with the supplier.

It represents a marketing activity where the outcomes of exchange may depend on bargaining, negotiation, power, conflict, and shared meaning between buyer and seller (Bagozzi, 1978).

Wilson (1995) emphasizes that value shared between dyadic can serves to improve the relationship, subsequently that they each can add more advantage from collaboration. Wilson (1995) advises that value creation brings the two closer and that the outcome of this closeness is that the parties are less able to find a suitable replacement. And he says "that value is produced in many different ways, which can include an enhance in social bonding." It is our contention that the performance of the service is enhanced when a social bond exists between the salesperson and the customer, and that this bond adds value to the relationship between the parties by distinguishing the service encounter in such a way that leads to customer satisfaction. Berry (1995) agrees by suggesting that value-adding benefits provided by the vendor firm provide the basis for an immutable and continuing relationship.

\subsubsection{STRUCTURAL BOND:}

Structural bond in a buyer-seller exchange relationship can come with and from economic effects for that relationship. These effects are due to increased efficiency and effectiveness in operations and value-creation shared by both partners. This bond is forged when two organizations is adapted to the other in a technical way, such as when adjusting a product or process. The benefits of a marketing exchange depend on the ability of each prospective supplier to create and sustain a competitive advantage over all other competitors" (Day \& Wensley 1983. Structural bond refer to the bonds related to structure, control, and institutionalization of norms of the relationship, the rules, policies, procedures or agreement that provides a formal structure to the relationship; All these actions can provide psychological, legal or physical link that connects the part of the relationship and making it difficult to substitution partners exchange. Structural bonding can be defined as applying, tactical relationship marketing that generate value to the customer and either engage investments by the buyer that cannot be returned if the relationship ends, and/or may be expensive if the buyers must provide this service themselves if they change sources" (Turnbull \& Wilson 1989).

\subsection{MARKETING ETHICAL DIMENSION:}

P. E. Murphy et al. (2007) theorized that Relationship Marketing is basically an ethical matter because a moral foundation is key to enduring relationships. They approved multiple ethical variables, but they anticipated the use of "virtue ethics" founded on good ethical practice. They posited that there are three basic virtue ethics in RM, trust, commitment, and diligence-that focus on personals and organizations rather than problems or dilemmas. Is an additional criterion that Murphy et al (2007) formulate These authors characterize diligence as the effort or persevering application of an actor to maintain a relationship. And they conclude that: companies that exhibit diligence will foster ethical RM." To justify their opinion they argue that "if they were unethical, the relationship would likely fall apart". The key ethical principles of trust, equity, responsibility, and commitment build customer loyalty toward the supplier (Gundlach \& Murphy, 1993).

\subsubsection{TRUST AND COMMITMENT}

Trust is seen as the key virtue that allows exchanges to move from transactional to relational. Trust has been defined and identified as the required antecedent to commitment (Morgan \& Hunt, 1994). Diligence is the effort that is put into the relationship to keep the trust and commitment active. P. E. Murphy et al. proposed that application of the virtue ethics can exist only in an organization that is customer-centric and values dialogue, collaboration, and partnership with customers.

\subsubsection{EQUITY}

Adopted by ( Admas 1963 Homans, 1961; Walster et al., 1978)) in Equity theory offers appropriate support for investigating the creation and appropriation of value in dyadic relationship. With reference in social psychology, equity theory gives explanation to the sharing of outcomes in interpersonal and inter-organizational relationships. Equity theory obtains practical support from different research fields (Austin \& Walster, 1975) (Adams, 1965) anticipated that the central principle of fair share is that outcomes must be proportional to an 
individual's contributions. However, other allocation norms exist that can be suitable at other times. Social exchanges frequently involve judgments of justice. A large amount of justice study has paying attention on perceptions of distributive fairness, which is the intuitive evaluation of outcomes as being just or unjust. Procedural fairness has also been examined as a relational dimension_ that is, as an indication of the social links between individuals and the groups they belong to.

(Bies \& Moag, 1986) Suggested that this relational aspect should be considered as an in- dependent dimension of fairness, and described it interactional fairness. A key dimensions of interactional fairness are truth fullness (Bies and Moag, 1986), friendliness, interest, honesty (Clemmer, 1993), and effort to resolve the conflict (Folkes, 1984; Mohr \& Bitner, 1995). The procedural fairness considered as an antecedent of satisfaction.

\subsection{RELATIONSHIP VALUE AS SOURCE OF DIFFERENTIATION:}

Fournier and, al identified for more analysis of the value foundations of relationship marketing. Several articles have examined the notion of value and ethics in relationship marketing: the ethical and legal foundations of relational exchange (Gundlach \& Murphy, 1993), relational norms can lead to both positive economic self interest as well as commitment and satisfaction outcomes (Joshi, 1994); trust worthiness promise keeping and justice are keys to understanding Relationship marking (Soellner, 1996) and commitment is central to relationship marketing (Gruen \& al, 2000). The notion of relationship value has appeared as an estimate for relationship outputs (Corsaro \& Snehota, 2010; Ulaga \& Eggert, 2006).

Relationship value can be defined as the sum of the benefits and cost reductions generated in an ongoing exchange with a business partner (Lefaix-Durand et al., 2009). Value is regard as be an important component of relationship marketing and the aptitude of a firm to increase superior value to its clients. This aptitude has become a source of differentiation and a key to the challenge of how to acquire and maintain competitive advantage" (Ravald \& Grormxjs 1996.;Nilson 1992; Treacy \& Wiersema 1993). Different descriptions presented in the marketing literature defining value like perceived value, desired or value judgment (Flint at al. 1997). Perception Value concerns implicit reason that guide behavior .desired value concerns what customer needs. Finally value judgment concerns an evaluation of the value; it is an evaluation of what has happened. Customer perceived value is considered the fundamental basis of competitive advantage for companies (Slater \& Narver, 1994; Woodruff, 1997).

Value is a complex construct and its use within the literature varies considerably (Lin et al. 2005). Current consensus in the marketing literature is that customer perceived value can be defined as the rade-off between the benefits and sacrifices perceived by the customer (e.g. Flint et al. 1997). Value perceptions of the same offering have been found to vary for example relative to situation, time, experience, and competition (Eggert and Ulaga 2002).

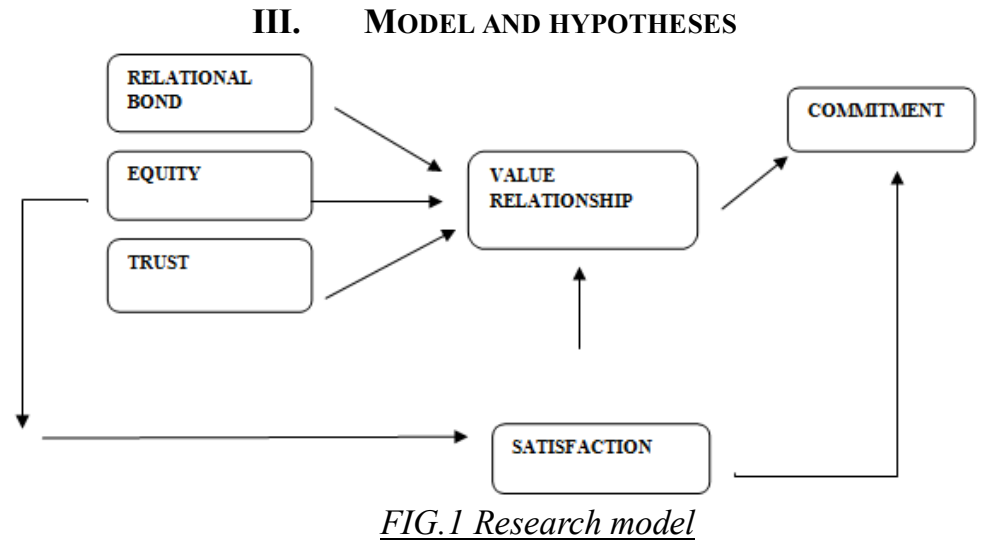

\subsection{RELATIONAL BOND AND VALUE RELATIONSHIP}

Du, Kamakura, \& Mela 2007; Fink et al., 2007; Gummesson, 1998, 2004; Morris \& Carter 2005; B. Murphy et al., 2005; Pitta et al., 2004) (Berry 1995) has indicated that relationship marketing and higher levels of relational bonds have a positive effect on exchange outcomes. Specially on satisfaction ( JamilaJouali, A.chakor 2013).

H1. Structural bond has significant influence on value relationship

H2. Social bond has considerable influence on value relationship

\subsection{EQUITY AND VALUE RELATIONSHIP}

Equity of the distribution the profits or the losses, between the parties in the objective to maintaining a long-term relationship considered as source of fairness in the dyadic relationship. 
Is the perceived fairness, Goodwin \& Ross (1992) established a relative link between customer perceptions of fairness and value of the service received.

\section{H3. Perceived equity has significant influence on value relationship.}

\subsection{EQUITY AND SATISFACTION}

The marketing literature indicates that equity has considered as en essential antecedent of satisfaction (Oliver, 1993) empirically studies have shown that customer equity perceptions impact the level of customer satisfaction (Hellier et al., 2003).

\section{H.4 Equity has significant influence on buyer satisfaction}

\subsection{SATISFACTION AND VALUE RELATIONSHIP}

Satisfaction is an emotional response to the judgment of a seller (Babin \& Griffin, 1998). We recommended that value perceptions contain particularly salient and indicative information that buyers utilize when apprising a seller. Additionally, over time, as buyers refine this appraisal, customer value will continue to influence satisfaction and may even become more influential as other less diagnostic information is devalued. Both the investment model and social exchange theory identified that outcome values (i.e., benefits received minus costs paid) of the current relationship positively influence satisfaction.

\section{H5. Relational satisfaction has a positive impact on value relationship}

Commitment is the main determinant of development seller buyer relationships over time. And Satisfaction is one of the major determinants of the long-term orientation. The customer satisfaction makes easier his engagement towards personnel (Romàn \& Ruiz 2005; Johnson et al. 2001).

\section{H6: Relational satisfaction has a significant impact on commitment}

\subsection{TRUST AND VALUE RELATIONSHIP}

The trust is defined as the expectation that one can rely on an actor to complete its obligations; it will behave predictably and will act and negotiate fairly in the case of opportunism. Buyer relationship outcome can only increase when the buyer has "confidence in an exchange partner's reliability and integrity" (Morgan \& Hunt 1994, p. 23). Safety, credibility and security are believed to reduce the sacrifice for the buyer in a collaboration and therefore lead to superior value (Ravald \& Grönroos 1996). Superior relational trust leads to positive results and helps generate outcome in ways that a transactional relationship could not effectively create or share among partners (Palmatier et al., 2006). As a result, we suppose the following:

H7. Relational trust has considerable influence on value relationship.

\subsection{VALUE RELATIONSHIP AND COMMITMENT}

In our study we defined buyer commitment as the intention of a buyer to maintain a continuity of relationship with a sellers. We suppose that a buyer's want to involve with a seller in future is fundamentally based on positive experience and positive judgment with the past relationship. Social exchange theory argues that the intention to stay with an exchange partner depends on how the partners perceive reward and cost (Homans 1958). So we consider buyer relationship value as a fundamental antecedent of commitment and suppose the subsequent:

H.8 Values relationship has considerable influence on buyer commitment

\subsection{RESEARCH CONTEXT.}

\section{Research design and methodology}

Morocco's small and medium-sized enterprises (SMEs) have been the goal of a large set of initiatives in recent years by a diversity of public and private institutions to assist develop SME admission to financial support and ability building. Today the economic and industrial fabric of each country depends on the performance of its SME-SMIs. They are pivotal, firstly as effective economic players, secondly as either upstream or downstream partners to major companies. In Morocco the growth of SME-SMIs is undeniably slow. This has led public policy to implement a set of institutional measures over the last few years to incite, support and encourage the most dynamic SMEs. These supportive measures, even though important and necessary, have had a limited effect. The current economic situation confirms the decadence of the Moroccan industrial sector and the continuing degradation of exports due to a loss of competitiveness of the SMEs as opposed to importers. The admission to financial support by banks is still restricted because of the protection necessary. In order for these SMEs to remain a motor for expansion it is important to sustain their relationship with the supplier specifically their Bank as provider services for get hold of value relationship. The intention of this paper is to comprehend the different dimensions to maintain their relationship. The financial service offered the environment in which to test the study hypotheses. To improve the validity of the measurements, a number 
of steps were used. A rigorous study of the literature may be identifying dimensions for the related constructs. Wherever possible, existing measures that had been used in precedent works were adopted. The questionnaire was iteratively modified according to reaction received from the managers. A pilot test was accomplished among Moroccan SMEs. The questionnaire was further revised based on the data provided by the pilot test.

\subsection{MEASURES}

Overall a relational trust measure was adapted from Doney \& Cannon's (1997). Relational satisfaction was abstracted as a cumulative, global assessment based on his experience (Crosby et al. (1990). Perceived equity was adapted from Hellier et al. (2003). Commitment' items taken from (Morgan \& Hunt, 1994). Value relationship adaptred from Eggert \& Ulaga (2002), All the afore- mentioned measures used 7-point Likert-type scales. Social and structural bond measures were adapted from (Han. 1991)Berry [1995], Gwinner \& al. [1998], (Crosby et al. [1990) (Hsieh, Lin \& Chiu 2001)

\subsection{STRUCTURAL EQUATION MODELING:}

Structural equation modeling with AMOS 18.0 is used as the analytic tool. Model fit is assessed using

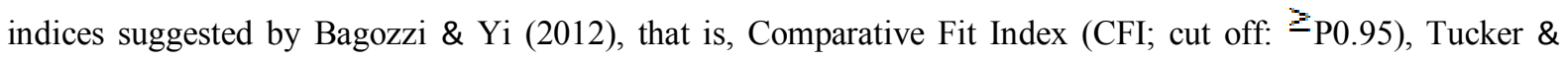
Lewis Index (TLI; cut off: $\geq 0.95$ ), Root Mean Square Error of Approximation (RMSEA; cut off: $\leq$ 0.06), and Standardized Root Mean Square Residual (SRMR; cut off: $\leq 0.07$ ). To assess the constructs, we conducted confirmatory factor analysis (CFA) using AMOS. Based on the CFA results, establishing the validity component of a measure involves two elements: convergent validity and discriminant validity (Campbell \& Fiske, 1959). We analyzed convergent validity, discriminant validity, and reliability of all the multiple-item scales, following the guidelines from previous literature (Fornell, Larcker, 1981; Gefen, Straub, 2005). The means, standard deviations, inter-construct correlations and square-root of average-variance-extracted (AVE) scores are reported in Table2. All pairs of inter-construct correlations are positive and significant $(\mathrm{p}<0.05)$. The means range from 2.56 to 3.60 (out of 5.0), and corresponding standard deviations range from 0.83 to 0.98 . Multicollinearity diagnostics did not signal a serious Threat in the data.

the reliability of the four latent factors is considered acceptable, as the Cronbach's Alpha and the composite reliability coefficients offer values which, in all cases, are appreciably higher than the recommended value of 0.7 (Bagozzi, Yi, 1988). Reliability was assessed in terms of composite reliability, which measures the degree to which items are free from random error and therefore yield consistent results. Composite reliabilities in our measurement model ranged from 0.71 to 0.86 (see Table 2, above the recommended cutoff of 0.70 (Fornell, Larcker, 1981). Discriminant validity was tested by comparing the average variance extracted by each construct to the shared variance between the construct and all other variables. For each comparison, the explained variance exceeded all combinations of shared variance (see Table 1). The estimated correlation matrix between the constructs is shown in Table 2. Hence, discriminant validity is deemed acceptable in the current study. Table 2 shows the inter-construct correlations off the diagonal of the matrix. Comparing all the correlations and square roots of AVEs shown on the diagonal, the results indicated adequate discriminant validity.

Table1. Means, standard deviations, scale reliability, AVE and correlations

\begin{tabular}{llllllllll}
\hline & Mean & SS.D & 1 & 2 & 3 & 4 & 5 & 6 & 7 \\
\hline Socia & 3.22 & 0.96 & 0,78 & & & & & & \\
Struc & 3.32 & 0.98 & 0,44 & 0,85 & & & & & \\
Equi & 3.34 & 0.94 & 0,33 & 0,49 & 0,93 & & & & \\
Satis & 2.56 & 0.95 & 0,13 & 0,32 & 0,45 & 0,86 & & & \\
Comm & 2.98 & 0.88 & 0,45 & 0,46 & 0,33 & 0,77 & 0,94 & & 0.89 \\
Valu & 3.50 & 0.83 & 0.46 & 0.22 & 0.39 & 0.44 & 0.03 & 0.88 \\
Trus & 3.6 & 0.85 & 0.21 & 0.30 & 0.36 & 0.25 & 0.05 & 0.12 & 0.88 \\
\hline
\end{tabular}


Table2. Reliability and validity estimates.

\begin{tabular}{|c|c|c|c|c|}
\hline Items & $\begin{array}{l}\text { Convergent } \\
\text { validity }\end{array}$ & Alpha & $\begin{array}{l}\text { Composite } \\
\text { reliability }\end{array}$ & AVE \\
\hline $\begin{array}{ll}\text { Equity } & \\
- & \text { Equity Being treated } \\
\text { fairly } & \\
\text { - } & \text { Being treated right } \\
\text { (justly and honestly) }\end{array}$ & $\begin{array}{l}0.62 \\
0.71\end{array}$ & 0.78 & 0.77 & 0.62 \\
\hline $\begin{array}{l}\text { Social bond } \\
\text { - } \\
\text { If I were to drop this } \\
\text { partner, I would lose a } \\
\text { good business friend } \\
\text { I have special social } \\
\text { relations with this firm }\end{array}$ & $\begin{array}{l}0.77 \\
0.87\end{array}$ & 0.75 & 0.83 & 0.55 \\
\hline $\begin{array}{l}\text { Structural bond } \\
\text { - } \\
\text { Provides personalised } \\
\text { service according to } \\
\text { my needs } \\
\text { - Provides integrated } \\
\text { service with its partners } \\
\text { - Offers new information } \\
\text { about its products/ } \\
\text { services of offers } \\
\text { frequently } \\
\text { innovative } \\
\text { products/services }\end{array}$ & $\begin{array}{l}0.76 \\
0.69 \\
\\
0.77 \\
0.79\end{array}$ & 0.73 & 0.86 & 0.61 \\
\hline 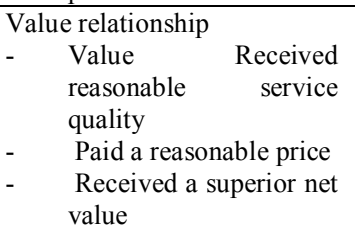 & $\begin{array}{l}0.89 \\
0.76 \\
0.78\end{array}$ & 0.85 & 0.79 & 0.68 \\
\hline $\begin{array}{l}\text { Relational satisfaction } \\
\text { - We were very satisfied } \\
\text { with the relationship } \\
\text { with seller } \\
\text { - We were happy to work } \\
\text { with seller. } \\
\text { - The relationship with } \\
\text { this seller was very } \\
\text { good for us. }\end{array}$ & $\begin{array}{l}0.75 \\
0.73 \\
0.72\end{array}$ & 0.91 & 0.75 & 0.59 \\
\hline $\begin{array}{l}\text { Relational trust } \\
\text { - } \text { Seller kept promises it } \\
\text { made to our firm. } \\
\text { - Seller was always } \\
\text { honest to us. } \\
\text { - We believed the } \\
\text { information that seller } \\
\text { provided us. } \\
\text { Seller was genuinely } \\
\text { concerned that our } \\
\text { business succeeded. } \\
\text { When making } \\
\text { important decisions, } \\
\text { seller considered our } \\
\text { Wel fare as well as its } \\
\text { own. } \\
\text { We found it important } \\
\text { to be careful with this } \\
\text { seller }\end{array}$ & $\begin{array}{l}0.76 \\
0.77 \\
0.79 \\
\\
0.75 \\
0.73 \\
\\
0.90\end{array}$ & 0.87 & 0.71 & 0.67 \\
\hline $\begin{array}{l}\text { Commitment } \\
\text { - We are very involved to } \\
\text { the relationship With } \\
\text { this Seller } \\
\text { The relationship that we } \\
\text { have with this Seller is } \\
\text { very significant to us } \\
\text { The relationship that we } \\
\text { have with this seller is } \\
\text { of very little } \\
\text { significance to us }\end{array}$ & $\begin{array}{l}0.73 \\
0.75 \\
\\
0.88 \\
0.82 \\
0.71 \\
0.80\end{array}$ & 0.88 & 0.72 & 0.66 \\
\hline
\end{tabular}




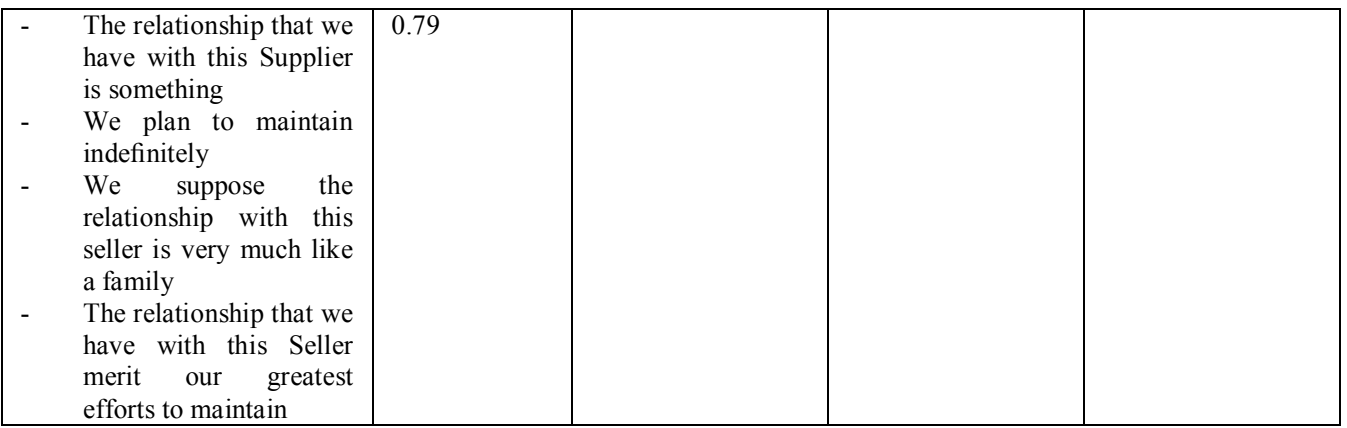

Finally, all factor measurement model of the current study (analyzed using confirmatory factor analysis in SEM) reveals an acceptable fit to data, that is, $\chi 2 / \mathrm{df}=2,80<3, \mathrm{p}<0.05$, TLI $=0.98, \mathrm{CFI}=0.94$, SRMR $=0.034$, RMSEA $=0.07$. Thus, adequate construct validity can be assumed in the current study.

Table3: Structural parameters of the research model.

\begin{tabular}{|c|c|c|c|c|c|}
\hline Path & $\begin{array}{l}\text { Estimat } \\
\mathrm{e}\end{array}$ & B & C.R. & $\mathrm{P}$ & $\begin{array}{l}\text { Hypothesis } \\
\text { support }\end{array}$ \\
\hline $\begin{array}{l}\text { Social bond } \\
\text { relationship }\end{array}$ & 1,951 & 0,35 & 8,85 & $* * *$ & Supported \\
\hline $\begin{array}{l}\text { Structural bond } \rightarrow \text { value } \\
\text { relationship }\end{array}$ & 0,889 & 0,78 & 10,21 & $* * *$ & Supported \\
\hline $\begin{array}{l}\text { Equity } \\
\text { relationship }\end{array}$ & 1,000 & 0,78 & 8,45 & $* * *$ & Supported \\
\hline Trust $\rightarrow$ value relationship & 1,945 & 0,59 & 7,36 & $* * *$ & Supported \\
\hline $\begin{array}{l}\text { Value relationship } \\
\text { Commitment }\end{array}$ & 1,302 & 0.55 & 7,15 & $* * *$ & Supported \\
\hline Equity $\rightarrow$ Satisfaction & 1,860 & 0,42 & 6,33 & $* * *$ & Supported \\
\hline $\begin{array}{l}\text { Satisfaction } \quad \rightarrow \quad \text { Value } \\
\text { Relationship }\end{array}$ & 1,363 & 0,33 & 5,89 & $* * *$ & Supported \\
\hline Satisfaction $\rightarrow$ Commitment & 0,992 & 0,52 & 4,262 & $* * *$ & Supported \\
\hline
\end{tabular}

standardized beta coefficient; CR refers to critical ratio; $p$ refers to significance level. I/ $p<0.001$.

Individual hypotheses are examined next. Examination of path estimates reveals that all the direct hypothesized paths are significant (refer to Table 3). Endorser social bond exerts a direct significant impact on Value relationship $(b=0.35$, C.R. $=8.85)$, supporting H1. Structural bond, as expected, significantly impact on value relationship $(b=0.78, C . R .=10.21)$, thereby supporting $H 2$. Equity exerts direct significant influence on value relationship $(b=0.78, C . R .=8.45)$, as well as Satisfaction $(b=0.40, C . R .=7.24)$. Thus, Hypotheses H3 and $\mathrm{H} 4$ are supported. Satisfaction exerts a direct significant impact on value relationship $(b=0.33$, C.R. $=$ 5.89), as well as commitment ( $b=0,52 \quad, \mathrm{CR}=4,262) \mathrm{H} 5$ and $\mathrm{H6}$ are supported . Trust ( $\mathrm{b}: 0,59, \mathrm{CR}=7,36)$ directly and significantly impact on value relationship. Value relationship as expected significantly impact on commitment $(b=0,55, \mathrm{CR}=7,15) \mathrm{H} 7$ and $\mathrm{H} 8$ are supported.

\section{Managerial Implications}

Several important managerial implications come from our practical findings for managers. For sellers, buyers, customer relationships in general present direct income impact and should hence be guarded and stabilized. For doing consequently, attractive relationship value for their buyers is more useful than growing switching costs. Social, structural, equity and trust as positive impact on value relationship, as an ethical dimension, an important implication suggests that the relational bond both social and structural between dyad has a significant effect on the relational outcome resulting from dyadic exchange. Bonding makes easy direct profits through the diminution of the overall costs. This is possible because the social and structural bond assists to manage activities and avoids problems at the point of sale. Refer to revious research has produced a positive association between structural bonding strategies and outcomes Gounaris, 2005; Palmatier, Dant, \& al., 2006). Gundlach \& Murphy (1993) identified the relation between ethical dimensions and value in relational exchange. Have exposed that the commitment of a buyer to a seller is considerably influenced when the buyer perceived superior value, and is satisfied with precedent contact. The relationship equity impacts significantly on buyer's satisfaction and satisfaction impact value relationship. Confidently, it suggests that the firm has to foster relationship equity by maintaining relationship with customers that will help customers stick to the firm. 


\section{Limitation:}

This study has certain limitations attached by specific context. While some variables in our study were bilateral (e.g., value relationship, trust commitment and satisfaction), we focused in our study of buyer perception. We then identify that advance research on inter organizational and marketing relationship must aim at the testing of reciprocally the seller and the buyer side. Finally, the illustration of Moroccan firms can limit the difference of a number of the variables and may reflect market specificity of this context. Therefore, further research is encouraged to reproduce the present work in other research settings. Among the future lines of research the most immediate include the consideration of new variables associated to relationship marketing such as loyalty, dependency; communications and other relational dimensions.

\section{References:}

[1] Anderson, J.C. (1995) Relationships in business markets: Exchange episodes, value creation, and their empirical assessment In: Journal of the Academy of Marketing Science Volume 23, No.4, pp.346-350

[2] Anderson, J.C.-Narus, J.A. (1990) A model of distributor firm and manufacturer firm working partnerships In: Journal of Marketing Volume 54, No.1, pp.42-5

[3] Arantola, Heli (2002), "Consumer Bonding- A Conceptual Exploration,” Journal of Relationship Marketing, 1(2), 93-107.

[4] Bendapudi, N., \& Berry, L. L. (1997). Customers' motivations for maintaining relationships with service providers. Journal of Retailing, 73(1), 15-37.

[5] Berry, L.L. 1995. 'Relationship marketing of services-Growing interest, emerging Perspectives.' Journal of the Academy Of Marketing Science, 23, 4, 236-45.

[6] Bies, Robert J., \& Moag, Joseph S. (1986). Interactional justice: Communication of criteria of fairness, In R. J. Lewicki, B. H. Sheppard, \& M. H. Bazerman (Eds.) Research on negotiations in organizations (pp. 43 - 55). Greenwhich, CT: JAI Press.

[7] Boedecker KA, Morgan FW, Stoltman JJ. Legal dimensions of salesper- son's statements: a review and managerial suggestions. J Mark 1991; 55:70-80.

[8] Callaghan, M., McPhail, J., and Yau, O.H.M. (1995). Dimensions of a relationship marketing orientation. Proceedings of the Seventh Biannual World marketing Congress, Melbourne, July.

[9] Clemmer, Elizabeth C. (1993). An investigation into the relationship of fairness and customer satisfaction with services. In R. Cropanzano (Ed.) Justice in the workplace: Approaching fairness in human resource management (pp. 193 - 207). Hillsdale, NJ, England: Lawrence Erlbaum.

[10] J .JOuali, A.Chakor "collaboration in Buyer-Seller Relationships as a New Approach to Competitive Advantage IOSR Journal of Business and Management (IOSR-JBM) Volume 10, Issue 2 (May. - Jun. 2013), PP 55-64

[11] Colquitt, Jason A. (2001). On the dimensionality of organizational justice: A construct validation measure. Journal of Applied Psychology, 86(June),

[12] Corsaro, D., \& Snehota, I. (2010). Searching for relationship value in business markets: Are we missing something? Industrial Marketing Management, 39(6), 986-995.

[13] Day, G.S., Wensley, R. (1983), Marketing Theory with a Strategic Orientation". Journal of Marketing, vol. 47, Fall, p. 79-89

[14] Deutsch, Morton (1973). Equity, equality, and need: What determines which value will be used as the basis of distributive justice? Journal of Social Issues, 31(3), $137-149$.

[15] Ford D. (1980) the developpement of buyer-seller relationships in industrial markets, European Journal of Marketing, 14, 5/6, 339353.

[16] Fornell, C., \& Larcker, D. F. (1981). Evaluating structural equation models with unobservable variables and measurement error. Journal of Marketing Research, 18(1),39-50.

[17] Goodwin C. et Ross I. (1992), Consumer responses to service failures influence of procedural and interactional fairness perceptions, Journal of Business Research, 25, 2, 149 .

[18] J. JOUALI, A.Chakor "Governance of Buyer Supplier Relationship in Morocco Context: Qualitative Study" Vol 5, No 16 (2013) European journal of business and management

[19] Gundlach GT, Murphy PE. Ethical and legal foundations of relational marketing exchanges. J Mark 1993; 57(October):35-46.

[20] Hakansson, H. ed. (1982) International Marketing and Purchasing of Industrial Goods: An Interaction Approach, Chichester, John Wiely \& Sons

[21] Homans, G. C. (1961). Social behavior: its elementary forms. New York: Harcourt, Brace, \& World.

[22] Lagace, RR, R. Dahlstrom \& JB Gassenheimer. 1991. 'The relevance of ethical salesperson behavior on relationship quality: the pharmaceutical industry.' Journal of Personal Selling and Sales Management, 39-47

[23] Lefaix-Durand, A., Kozak, R., Beauregard, R., Poulin, D., 2009. Extending relationship value: observations from a case study of the Canadian structural

[24] Morgan et Hunt (1994), Morgan, RM., and Hunt, S.D., 1994. The commitment-trust theory of relationship marketing. Journal of Marketing. 58 (July), 1994.

[25] Morris, M., \& Carter, C. (2005). Relationship marketing and supplier logistics performance: An extension of the key mediating variables model. Journal of Supply Chain Management, 41, 32-44

[26] Murphy, P. E., Laczniak, G. R., \& Wood, G. (2007). An ethical basis for relationship marketing: A virtue ethics perspective. European Journal of Marketing, 41(1/2), 37-57.

[27] Palmatier RW, Dant RP, Grewal D, Evans KR. Factors influencing the effectiveness of relationship marketing: a meta-analysis. J Mark 2006;70(4):136-53.

[28] Pitta, D. A., Franzak, F. J., \& Little, M. W. (2004). Maintaining positive returns in the value and supply chain: Applying tomorrow's marketing skills. Journal of Consumer Marketing, 21(7), 510-519.

[29] Sin, Y.M., C.B. Tse, H.M. Yau, R. Chow \& S.Y. Lee. (2002). The Effect of Relationship Marketing Orientation on Business Performance in a Service-Oriented Economy. Journal of Services Marketing, 16 (7), 656-76.

[30] Stephan M. Wagner, Andreas Eggert Eckhard Lindemann 2010 'Creating and appropriating value in collaborativerelationships'http://www.scm.ethz.ch/publications/Academic_publications/Wagner_etal_2010_Creating_and_appropri ating value in collaborative_relationships.pdf

[31] Turnbull, P. \& Wilson, d. (1998) Managing Business Relationships. England: John wiley \& Sons ltd. 
[32] Ulaga W. et Eggert A. (2006), Value-Based Differentiation in Business Relationships, Gaining Key Supplier Status, Journal of Marketing, January, 70, 119-136.

[33] Wilson, D.-Möller, K. (1995) Business marketing: an interaction and network perspective, Boston, Kluwer Academic Publishers

[34] Wilson, D.T. (1995). An Integrated Model of Buyer-Seller Relationships. Journal of Academy of Marketing Science, 23 (4), 335 345 